\title{
Ekphrasis Makes Still Artifacts Speak: Taking "If National Treasure Can Talk" as Example
}

\author{
Liu Fen ${ }^{1 *}$ \\ ${ }^{1}$ Wuhan Technology and Business University Wuhan China 430065 \\ ${ }^{*}$ Corresponding author. Email:235555022@qq.com
}

\begin{abstract}
Answering the call of Chinese culture policy of "Telling Chinese stories well", CCTV documentary "If a National Treasure Can Talk" has successfully produced a model of telling stories well. This study holds that, it is the use of "Ekphrasis", an ancient term of "descriptive discourse that can bring things to life", that enables national treasure to have the function of "talk". With close reading method, this study analysed its mechanism of changing visual art into verbal art in this CCTV Ekphrastic commentary, that is, power of language, narrative impulse and imagination as a bridge of "Ekphrasis", to give enlightenment of "telling stories well" and "making cultural relics alive" in China and other culture.
\end{abstract}

Keywords: Ekphrasis, If National Treasure Can Talk, Power of Language, Narrative Impulse, Imagination

\section{INTRODUCTION}

"Telling the Chinese story well" has been regarded as an important way to cultivate cultural confidence and build cultural soft power in China. Answering the call of this culture policy, CCTV documentary "If a National Treasure Can Talk" (hereinafter referred to as "National Treasure") has successfully became a model work of telling the story of national treasure. How did the poetic commentary of "National Treasure" transform the still and silent cultural relics in the museum showcase into the glamorous national treasure in the documentary? What is the secret of language to make cultural relics resonate with the audience and thus live in the audience's mind? The answer must be enlightening for realizing the Chinese cultural policy of "telling the Chinese story well" and "making cultural relics come to life".

Chinese scholar Liu Yang [1]formulated a theoretical mode of interpreting a cultural relic in the commentary of "National Treasure" and pointed out its breakthrough lies in the discovery and interpretation of creation information. However, Liu Yang has not discussed in depth how to use language (the verbal art) to interpret the creation information embodied in visual art.

This research proposes that, it is the use of "Ekphrasis" that "National Treasure" enables the cultural relics to have the function of "talking", hence resonates with the audience and "lives" in the hearts of modern people. In another word, "Ekphrasis" has successfully transformed cultural relics from ancient and silent single text (spatial/visual art) to literary text (verbal art). Therefore, the study of how "National Treasure" uses "Ekphrasis" (the conversion mechanism) is an important issue to be explored to achieve "telling Chinese stories well" and "making cultural relics alive" in China.

\section{EKPHRASIS}

Ekphrasis is an ancient term of "descriptive discourse that can bring things to life" which was derived from rhetoric in ancient Greece and Rome. In the eighteenth century, it was used to refer to vivid and lifelike descriptions in literature, and a rhetorical device intended to enhance the effect of lifelike descriptions. In the early twentieth century, the critic George Saintsbury [2] defined it as "a series of descriptions designed to vividly present people, places, images, etc. in the imagination of people."

In 1955, the critic Spitzer [3] published "Ode to A Grecian Urn, or the Confrontation between Content and Metagrammar", and believed that "Ode to A Grecian Urn" was a typical poem of "Ekphrasis", "it belongs to a genre known from Homer and Okritos to Banas and Rilke, that is, the depiction of painting or sculpture by poetry." He pointed out, "this kind of depiction indicates a kind of artistic transformation", namely, the re-creation of artistic objects that can be perceived in sense through 
the medium of words. According to him, poetry of "Ekphrasis" contain the ability and process to transform silent visual art into auditory art, that is, make the silent visual art sound and tell.

Spitzer's article opened the research on the ancient topic of "Ekphrasis" in the twentieth century and aroused great attention to the relationship between poetry and visual art. In November 1986, the 10th International Poetics Symposium and many subsequent international academic conferences discussed the relationship between literature and visual arts, which deepened the research on "Ekphrasis" in the field of two symbol systems of text and visual art, and later extended to the works of images and music. "Ekphrasis" became a new humanities subject concerning history, culture, poetry, and visual arts.

Among the Chinese researchers, scholars such as Tan Qionglin [4], Zhang Yan [5], Li Xiaojie [6] and Ou Rong [7] studied European and American painting poems or literary works from the perspective of "Ekphrasis". Shen Yadan [8], Li Xiao [9] and others studied the general function and significance of "Ekphrasis". Among Chinese researchers, Professor Ou Rong has set a Chinese term of “艺格符换” for its dynamic conversion, whose research has further expanded the extension and connotation of "Ekphrasis" in China. To conclude, the Chinese researches mainly focus on study of "Ekphrasis" in western literary works rather than in Chinese context.

As an ancient but efficient artistic form, "Ekphrasis" can provide new approaches to the study of the "textimage relationship" [8] and to the problem of "how to tell Chinese stories well" as well as "how to make cultural relics speak".

\section{EKPHRASIS IN CCTV DOCUMENTARY "IF THE NATIONAL TREASURE CAN TALK"}

Taking a method of close reading Ekphrastic subtitles of the first season "Human Head Pot" in "National Treasure", this study analyses its linguistic features, its motivation (impulse of speaking in still spatial artwork) and the bridge (imagination) of its artistic conversion to explore how "Ekphrasis" in "National Treasure" ignites the fire of life of cultural relics and tells stories of ancient Chinese people successfully.

\subsection{Power of Language in Ekphrasis}

According to Ruth Webb [10], "Ekphrasis" is "a form of vivid evocation", which "appeals to the mind's eye of the listener, making him or her 'see' the subject-matter, whatever it may be." How does the Ekphrastic commentary of "Human Head Pot" use vivid evocation to appeal to the audience or listeners, allowing him or her to see it, communicate with it and understand the historical spirit connected with the modern life?
In the very beginning of "Human Head Pot", the Ekphrastic commentary uses the word "you" to give the human head pot the personality of speaking as well as a living person with "You come from the soil, and your head is slightly raised, as if looking up at the sky". With the leading word of "gazing" and "contemplating", the audience are led from observing this spatial artwork to thinking about abstract issues such as "meaning". Therefore, in producing the pot, human beings realize their extraordinary ability to create things. This is the first level of meaning exploration completed by the poem: creation makes human life meaningful.

Subsequently, the poem raises the second question to further explore its creation information of the pot: "New birth shines like the light, and death falls like the night. Human raise their questions of life and death generation after generation, and then dissolve in the soil again and again." Because of the thinking about life and death, human beings "began to gaze at themselves" and led to "the birth of visual art", which is a sign of the awakening of the world's ancient civilizations.

The text repeatedly uses uncertain and questioning words such as "as if, look up, think, know, question, approximate, seem, perplexed, indistinguishable, metaphoric, suggestive, perhaps" to trigger curiosity, imagination and thinking. According to Webb [11], "What distinguish Ekphrasis is its quality of vividness, enargeia, its impact on the mind's eye of the listener who must, be almost made to see the subject". Through the repeated use of verbs such as "gaze" and "look up", the poetry is directed from the flow of time art to the stillness of space art, creating expressions of repetition, flow and revolving. At the same time, the signifiers such as "you, us, those ancient people, mankind, the world's major ancient civilizations, billions of confused faces, women, their creators" and other referents extend the meaning of a pot to all mankind, and finally with the verbs such as "recognize", "awaken" and "see", the poem completes the closed loop of the gaze at the head pot and its circular structure.

\subsection{Narrative Impulse of Ekphrasis}

Heffernan [11] explored the narrative tendency implied by spatial artwork, pointing out that the spatial art itself is the reproduction of objects, while the literary or poetic text is a representation of the image in plastic art or the object itself. In another word, not only the literary text has the impulse and ability of narration, but also the spatial arts have the impulse of narration. As Mitchell [12] pointed out, "The image of the written image and the image of the picture is related to language rhetoric from the beginning, that is, the way of speaking is inseparable."

When the human head pot was created more than 6,000 years ago during Yangshao culture period, its 
narrative impulse was obviously presented. Archaeological findings indicate that burial system was female-centred in Yangshao culture period and the abdomen of women was also the worship of reproduction. To learn about the function and meaning of this human head pot, we can only use our imagination and limited historical clues to resonance with the maker.

Erwin Panofsky [13] believes that we can describe images from the level of phenomenological significance, because such a description only requires us to observe the artwork and connect it with similar concepts in our life experience. As the phenomenological meaning is revealed, the meaning based on the content will gradually be revealed [9].

The Ekphrastic commentary connects the pot with our life experience and finally with the knowledge of the style of red clay pottery in Neolithic Age and the knowledge of typology of Yangshao culture, thus reveals the phenomenological meaning, content meaning and connotative meaning of the pot in the form of visual art, which is Panofsky once defined, the unconscious and subconscious self-revelation of the basic concepts of the world of the visual art.

\subsection{Imagination as Bridge of Ekphrasis}

Vico [14] believes that primitive humans have great similarities with real children with strong imagination. Similarly, Collingwood [15] pointed out that human language is "imaginative and expressive in its primitive state". The Roman rhetorician, the great Philo Stratos portrayed Greek paintings and statues in his "Imagination" with his own imagination, which indicates the relationship between reality and imagination in early Ekphrastic poems. Lilachman [16] also pointed out Poussin's paintings and Keats's poems "Both artists lead their audiences (readers) to what they want to reproduce and imagine." The reproduction of visual art in Ekphrastic poetry is the result of the artistic imagination and active recreation of the visual art the poet is facing.

As a spatial artwork full of imagination and creation, the Ekphrasic commentary of "human head pot" leads the audience to imagine and think with it, and successfully extends the impulse of speaking of the artwork to the universal expression of human beings. Therefore, imagination acts as the bridge between objects and their visual art or verbal art.

\section{CONCLUSION}

Traditional epistemology believes that image and language are in the binary. Ekphrasis breaks this duality with the use of language to create pictures and develops a new feeling of language, which actually changes the way people understand the world. CCTV commentary "If National Treasures Can talk" uses the poetic language of
"Ekphrasis", which enables the commentary to transform the silent visual art into the sound and emotional verbal art, so that the cultural relics can "talk" with modern people, evoke their imagination and empathy, and therefore "live" in the collective memory of the Chinese nation in modern times.

To summarize, the study on the conversion mechanism of how "National Treasure" uses "Ekphrasis" successfully transforms cultural relics from ancient and silent single text (spatial / visual art) to literary text (verbal art) is beneficial to realize "telling stories well" and "making cultural relics alive" successfully in China as well as in other culture.

\section{ACKNOWLEDGMENTS}

This article is one of the phased achievements of the Key Project "Modern Aesthetic Education Research on Traditional Chinese Decorative Arts" of the Ministry of Education of National Educational Science "Thirteenth Five-Year Plan” (Approval Number: DLA200364)

\section{REFERENCES}

[1] Y. Liu, Multi-dimensional Interpretation of Museum Collections: A Grounded Theory Based Study on the Voice-Over Script of If National Treasures Could Tal, Southeast Culture, vol. 3, 2019, pp.104-109.

[2] G. Saintsbury, A History of Criticism and Literary Taste in Europe from the Earliest Texts to the Present Day, W. Blackwood and Sons, New York, 1992, pp. 491.

[3] L. Spitzer, The "Ode to a Grecian Urn", or Content vs Metagrammar, Comparative Literature, vol.7, 1955, pp. 207.

[4] Q. L.TAN, Ekphrasis: A New Disciplinary Science of Humanities, English and American Literary Studies, vol.1, 2010, pp. 301-319.

[5] Y. Zhang, Let the Silent Ancient Urn Make a Sound: Ekphrasis and imagination of Keats" "Ode on a Grecian Urn”, Foreign Literature Review, vol. 2, 2017, pp. 167-182.

[6] X. J. LI, The Design of Poetic Text in Williams' Ekphrastic Poem "The Parable of the Blind", Foreign Language and Literature Research, vol. 6, 2018, pp. 34-43.

[7] R. Ou, Museum of Words: A Survey of Contemporary European and American Ekphrasic Poetics[J]. Journal of Shanghai Jiaotong University (Philosophy and Social Sciences), vol.4, 2020, pp. 126-137. 
[8] Y. D. SHEN, The Road to Revival of Ekphrasis and Its Contemporary Enlightenment, Jianghai Journal, vol.1, 2013, pp. 188-197.

[9] X. Li, Introduction to Erwin Panofsky's Origin of Graphics: On the Problem of Describing and Interpreting Works of the Visual Arts, Arts Exploration, vol. 4, 2018, pp.67-78.

[10] R. Webb, Ekphrasis ancient and modern: The invention of a genre, Word \& Image, vol.15, 1999, pp. 7-18.

[11] J. Heffernan, Ekphrasis and Representation, New Literature History, Vol22, 1991, pp. 299-301.

[12] W. J. T. Mitchell, Picture Theory: Essays on Verbal and Visual Representation, University of Chicago Press, 1994.

[13] E. Panofsky, J. Elsner, K. Lorenz, On the Problem of Describing and Interpreting Works of the Visual Arts, Critical Inquiry, vol. 1, 2012, pp. 467-482.

[14] G. B. Vico, New Science, Commercial Press, 1989.

[15] R. G. Collingwood. The Principles of Art[M]. Beijing: China Social Sciences Press, 1985, p. 232.

[16] L. Lilachman, Time, Space, and Illusion: Between Keats and Poussin, Comparative Literature, vol.55, 2003, pp. 298. 